\title{
Performance of Permanent Employees and Contract Employees in The Furniture Industry
}

\author{
Vera Firdaus \\ Faculty of Economics and Business, University of Muhammadiyah Sidoarjo, \\ Indonesia \\ *Corresponding author. Email: verafirdaus06@gmail.com
}

The furniture industry is a sector whose development is very competitive but tends to fluctuate in demand. High labor absorption in the furniture industry demands efficiency efforts so that labor does not become a production burden, so the company applies a contract system to employees. The purpose of this study is to analyze whether there is a significant difference between the performance of permanent employees and contract employees. The research was conducted in 2 companies in East Java. The sampling technique used cluster random sampling, so that 50 permanent employees and 50 contract employees were obtained as research samples. Data collection techniques through questionnaires, preliminary studies, interviews, observations and studies of scientific publications. The research design is quantitative with a two-sample comparative approach. Analysis using Independent Samples T Test with SPSS version 23 program. The results of the study prove that there area significant difference between the performance of permanent employees and contract employees of 1,820. Contract employees on average have better performance (mean 24.56) than permanent employees (mean 22.74).

Keywords: Performance, Permanent Employees, Contract Employees

OPEN ACCESS

ISSN 2528-4649 (online) ISSN 2338-4409 (print)

Reviewedby: Zarah Puspitaningtyas, Irwan Moridu

${ }^{*}$ Correspondence: Vera Firdaus verafirdaus06@gmail.com Received: June 8, 2021 Accepted: August 24, 2021 Published: September 27, 2021 JBMP: Jurnal Bisnis, Manajemen dan Perbankan. Vol: $7 /$ No. 2 doi:10.21070/jbmp.v7vi2.1540 


\section{INTRODUCTION}

The wood processing industry in Indonesia is experiencing rapid development, marked by the development of raw materials and products produced for both the domestic market share and export demand (Firdaus \& Handriyono, 2018). Modernization, changes and challenges that occur in the wood processing industry indicate that this sector has a competitive advantage. The manufacturing industry that has a competitive advantage will create value added creation and become a driver of the national economy (Desfiando, 2014), because of the large absorption of labor and the value of capital capitalization invested by entrepreneurs (Behun, et.al., 2018).

The wood industry has a big role in economic growth (Wirakusumah, 2014). The development of the wood industry, especially furniture, is marked by an increase in the number of industries, an increase in industrial land, the resulting outcomes and an increase in the number of workers working in this sector (Romy, et.al, 2015). The provision of employment in the furniture industry will have implications for economic growth because it reduces poverty (Kupčák \& mída, 2015; Wirakusumah, 2014; Farole \& Winkler, 2012).

According to Farole \& Deborah (2012), the furniture and wood industry is one of the sub-sectors that plays an important role in Indonesia's economic growth, in addition to the apparel and automotive components industry. However, the contribution of the furniture industry with wood raw materials tends to fluctuate. Data from the Central Statistics Agency shows that in East Java the furniture industry grew by 10 percent, namely 19.08 percent. The growth contraction is shown in table 1 below:

\section{[Table 1 about here.]}

Table 1 shows that the wood industry tends to experience an increase in export value by 0.56 percent from 2017 (by 0.13 percent) to 0.75 percent in 2018 . However, in 2019 it decreased by 0.8 percent.

The high competition in the furniture industry, the fluctuating value of demand for furniture products and the importance of adaptability to change have caused companies to set strategies to survive, be productive and innovative. The high-scale processed wood industry in production will tend to be efficient in factors related to the production process, so that the company can survive and develop rapidly (Sanjaya \& Budhi, 2017; Adzana, et.al, 2020). Management performs these efficiencies mainly related to raw material costs and labor costs (Arni, 2018).

Companies must integrate manufacturing operating systems with innovations and technologies that can drive increased productivity, reduce labor costs, material costs and processing time (Dalenogare, et.al, 2018; Facevicova \& Kynclova, 2020). Therefore the company must make efforts so that productivity is high but the resources owned are not excessive for the company, it can actually become a cost burden. Especially in the furniture industry, which uses a lot of labor, it is necessary to take into account the performance of the production department (Farole \& Winkler, 2012). Operationalization that occurs in the furniture industry results in operational performance that is influenced by the performance and productivity of employees who are interrelated between divisions (Castro, Figueiredo, Guizzo, \& Passos, 2019). So that employee competencies and skills play an important role for the productivity of other units or divisions (Fong \& Mahfar, 2013)

\section{LITERATURE REVIEW}

Companies that tend to fluctuate will apply cost efficiency in the production process, one way of efficiency is implementing a contract system. With a contract work system the company will be efficient in time, effort and funds (Hasro, 2020). Preliminary study through interviews with company management, employees actually prefer to work as contract workers because their wages are calculated based on performance. It is also possible for contract employees to be applied to jobs with certain characteristics or carried out to see the dedication and performance of employees before being appointed as permanent employees (Arif, 2012). The company's policy on temporary or contract employees is intended to reduce production costs in two ways: (1) cost balancing by externalizing activities through subcontracting services (2) limiting labor (Ferreira \& Santos, 2013).

\section{Permanent Employee \& Contract Employee}

The phenomenon is related to the use of contract employees in companies due to certain jobs that require certain types of skills and are contract (Anggraeni, Herlambang, \& Diansari, 2020). There are also companies that implement an employee management strategy by hiring contract employees (contracts, wholesale) as an effort to flexibility due to fluctuating labor needs (Haden, Caruth, \& Oyler, 2011).

Several opinions regarding the definition of permanent employees and contract employees indicate differences in the duration of work and the mechanism of rewards. Permanent employees can be defined as workers who receive financial rewards from their performance in a certain amount on a regular basis (Anggraeni, Herlambang, \& Diansari, 2020). Contract employees are workers who are paid for an unlimited duration with the nature of sub-contract work or incidental work (Zimmerman, et.al., 2013; Virtanen, et.al, 2005)

\section{Work Performance}

Performance is a multi-dimensional concept, which refers to an individual's ability to contribute to activities both technically and contextually (Mgalu, 2017). To improve individual performance and organizational performance, companies need to understand and revitalize in order to remain productive (Banerjee, 2015). The high performance that exists in individuals in the organization shows that what is done by the individual is in accordance with what was programmed by the organization. The contribution of employee performance will affect the development and excellence of the company (Florence, 2015). 
Experts provide a definition of performance related to job output. The definition of performance put forward by several experts. Performance is defined as the output and achievement of employees at work that is recognized by the company (Suciu, et.al. 2013). Mardiana, et al. (2017) stated the same thing about the definition of performance, namely the output generated from certain activity functions over a certain period of time.

There are three dimensions of employee performance, including task performance, contextual performance and adaptive performance (Tabiu, et.al, 2016). The indicators used to measure employee performance are those proposed by Tabiu (2016), To achieve organizational goals and objectives, employee performance must refer to work effectiveness and efficiency, which is followed up by evaluation of absenteeism levels, quality of reports, and reporting times ( Zainal, Veithzal Rivai. Basalamah, Salim., Muhammad Natsir, 2014).

Ahmed \& Shabbir (2017) mention three dimensions of performance, namely work efficiency, work effectiveness and job satisfaction. According to Syam (2020), work efficiency is a manifestation of the way employees work that allows them to achieve the best results with maximum effort. Work effectiveness is the quantity achieved with the expected output from the number of inputs. While job satisfaction is the attitude of employees towards their work by comparing the amount of rewards received with the amount they believe the employee should receive (Abadiyah \& Purwanto, 2016).

This research is based on empirical studies of previous research. The following previous studies show that there are differences between permanent employees and contract employees, namely in research (Mahaningsih \& Kana, 2020); (Kusuma, 2020)Nur, 2020; Anggraeni, et.al. 2020). While the following research shows that there is no difference in performance between contract employees and permanent employees (Wahyuningtyas \& Utami, 2018; Hasro, 2020; Firdausi, 2015; Kusuma, 2020). contract employees

\section{METHOD (FOR RESEARCH ARTICLE)}

Based on the objectives to be achieved, this research is a quantitative study with a comparative approach, namely by testing the population parameters in the form of a comparison of two samples. The comparative test is intended to find out whether two groups are different from each other by including the mean and standard deviation of the two groups on certain variables (Sekaran, 2016). The data analysis used is the Independent Samples T Test, namely by comparing the average of two samples (Sugiono, 2018). SPSS version 23 program for windows was used to test and analyze the questionnaire data.

This quantitative research data collection technique is a questionnaire by measuring two groups of samples, namely the permanent employee group and the second group the contract employee group. The variable measured is employee performance with three indicators, namely work efficiency, work effectiveness and job satisfaction which refers to the theory proposed by Ahmed \& Shabbir (2017).

Other data collection techniques that support this research include observation, interviews, field studies, and studies of scientific publications. The study was conducted in two companies engaged in the furniture industry in East Java, namely PT Karya Jati Sejati located in Keplaksari, Jombang Regency and PT Romy Violeta located in Buduran, Sidoarjo Regency, with two research samples, namely 50 permanent employees and 50 contract employees. The sampling technique used was cluster random sampling, namely dividing the population into groups, then randomly selecting the number of groups needed.

\section{RESULTS AND DISCUSSION}

Before analyzing the data, the researcher first conducted a Validity Test, Reliability Test, Basic Assumption Test, Normality and Homogeneity Test with the SPSS version 23 for windows program. The item validity test uses the Pearson correlation, namely by correlating the item score with the total score. The significance test with the criteria used $r$ table at a significance level of 0.05 with a 2 -sided test. If the value is positive and $r$ count $r$ table then the item can be declared valid, if $r$ count $<r$ table then the item is declared invalid or invalid. If $\mathrm{N}=100$ and the value of $\mathrm{df}=100-2$, then the value of $r$ table is 0.1966 . Here are the results of the validity test.

\section{[Table 2 about here.]}

The results of the validity test show that the 6 statement items have a value above $r$ table 0.166 so that it can be declared valid. The next test is the Reliability Test to find out the internal consistency of the indicators of a common construct or latent variable (Sugiono, 2018). The results of the reliability test are in table 4 below:

[Table 3 about here.]

[Table 4 about here.]

From the output of the homogeneity test in the table, it can be seen that the significance value is $>0.05(0.761>$ 0.05). This shows that the variance of Permanent Employees and Contract Employees is the same. Thus fulfilling the basic assumption of homogeneity.

\section{[Table 5 about here.]}

Table 5 Group Statistics shows that the average permanent employee performance is 22.74. Meanwhile, the mean of Contract Employee Performance is 24.56. This 
proves that there is a difference in the performance of permanent employees and contract employees.

[Table 6 about here.]

From table 6. independent samples test it is known that the value of Sig. Levene's Test for Equality of Variances is $0.761>0.05$. This shows that the data variance between permanent employees and contract employees is homogeneous (same).

[Table 7 about here.]

The output table for independent samples test shows the value of Sig. (2-tailed) of $0.001<0.05$. It can be concluded that there is a significant difference between the performance of permanent employees and contract employees. The means difference is $-1,820$, which means that contract employees on average have a better performance of 1,820 than permanent employees. This result is possible because in the furniture company there is diversity in education and knowledge.

Employees who have the skills feel more optimal in their performance and are more productive when they are contract employees. Because as a contract employee, the wages are calculated based on the results of production or the quality and quantity of work. The application of the work system turned out to make new employees who were appointed more motivated to show their performance so that they could be appointed as permanent employees. The results of this study are in accordance with previous research, namely
Mahaningsih \& Kana, (2020); Nur (2020) and Anggraeni, et.al. (2020).

The results of this study indicate that there is a significant difference between the performance of permanent employees and contract employees. Comparative testing of two samples using the Independent Samples $\mathrm{T}$ Test with SPSS version 23 program proves that contract employees on average have better performance than permanent employees. This is evidenced by the mean value of permanent employee performance of 22.74. Contract employees have a mean of 24.56 (with a mean difference of 1.820). This study still has limitations where satisfaction needs to be considered as a variable that affects employee performance.

\section{CONCLUSIONS}

Based on the results of theoretical studies and empirical testing, it can be concluded that there is a significant difference between the performance of permanent employees and contract employees. Comparative testing of two samples using the Independent Samples $\mathrm{T}$ Test with SPSS version 23 program proves that contract employees on average have better performance than permanent employees. This is evidenced by the mean value of permanent employee performance of 22.74. Contract employees have a mean of 24.56 .

\section{ACKNOWLEDGEMENT}

Write those who assist in research, especially funding your research supporters. Include individuals who have assisted you in your studies: Advisers, financial backers, or perhaps other supporters, namely Pro-readers, Typists, and Suppliers who may have provided material. 


\section{REFERENCES}

Abadiyah, R., \& Purwanto, D. (2016). Pengaruh Budaya Organisasi, Kompensasi Terhadap Kepuasan Kerja Dan Kinerja Pegawai Bank di Surabaya. Jurnal Bisnis, Manajemen \& Perbankan, 2, 49-67.

Ahmed, I., \& Shabbir, S. (2017). The Effects of Rewards on Employee's Performance in Banks: A Study of Three Districts (Lodhran, Vehari, Khanewal) Commercial Banks in Pakistan. International Review of Management and Business Research, 6(1), 352-361. Retrieved March 2017

Anggraeni, D., Herlambang, T., \& Diansari, T. (2020). Analisis Perbandingan Kinerja Karyawan Tetap Dan Karyawan Kontrak (Outsourcing) Pada Ptpn X Kebun Kertosari Jember. Jember: Program Studi Manajemen Fakultas Ekonomi, Universitas Muhammadiyah Jember. Retrieved from http://repository.unmuhjember.ac.id

Arif, F. P. (2012). Perbedaan Motivasi Kerja Antara Karyawan Kontrak Dan Karyawan Tetap Pada Pt. Bank Rakyat Indonesia Cabang Cimahi. Psympathic, Jurnal Ilmiah Psikologi, 5, 566-581. doi:https://doi.org/10.15575/psy.v5i2.2153

Arni, Y. (2018). Persentase Biaya Bahan Baku, Biaya Tenaga Kerja, Biaya Overhead Pabrik Terhadap Harga Pokok Produksi Pada Pt. Maju Tambak Sumur. Jurnal Neraca,: Jurnal Pendidikan dan Ilmu Ekonomi Akuntansi, 2, 43-56. Retrieved Juni 2018

Banerjee, A. (2015). Integrating Human Motivation In Service Productivity. In A. Banerjee (Ed.), 6th International Conference On Applied Human Factors And Ergonomics (AHFE 2015) And The Affiliated Conferences, AHFE 2015. 3, pp. 3591 - 3598. Elsevier B.V., Procedia Manufacturing. doi:https://doi.org/10.1016/j.promfg.2015.07.726

Behun, M., Gavurova,, B., Tkacova, A., \& Kotaskova, A. (2018). The Impact Of The Manufacturing Industry On The Economic Cycle Of European Union Countries. Journal of Competitiveness, 10(1), 23-39. doi:https://doi.org/10.7441/joc.2018.01.02

Castro, F., Figueiredo, P. S., Guizzo, C. P., \& Passos, F. U. (2019). Effect Of The Motivational Factor On Lean Manufacturing Performance: The Case Of A Multinational Consumer Goods Company. Gestão \& Produção, 26. doi:https://doi.org/10.1590/0104-530X4850-19

Desfiando, B. (2014). Peran United Nations Industrial Development Organization (UNIDO) Dalam Membantu Perkembangan Industri Manufaktur Indonesia 2010-2013. JOM FISIP, 1, 1-11. Retrieved Oktober 2014

Farole, T., \& Winkler, D. (2012). Export competitiveness In Indonesia's Manufacturing Sector. Kingdom Netherlands, The World Bank. Multi-Partner Facility. Retrieved December 2012

Ferreira, I., \& Santos, M. (2013). Análise da utilização de trabalho temporário em empresas portuguesas: riscos e alternativas. International Journal On Working Conditions, 18-38. Retrieved June 2013

Firdaus, V., \& Handriyono. (2018, July). The Effect Of Change Management And Managerial Skill To Employee Motivation. International Journal Of Scientific \& Technology Research, 7(7), 100-106.

Florence, O. (2015). Effect Of Communication On Employee Performance At Ghana Revenue Authority, Kumasi. Kwame Nkrumah University of Science and Technology, Department of Marketing and Corporate Strategy. Business Administration. Retrieved November 2015

Fong, Y. L., \& Mahfar, M. (2013). Relationship Between Occupational Stress And Turnover Intention Among Employees In A Furniture Manufacturing Company In Selangor. Jurnal Teknologi, 64, 33-39. Retrieved August 30, 2013

Haden, S. S., Caruth, D. L., \& Oyler, J. D. (2011). Temporary and Permanent Employment in Modern Organizations. Journal of Management Research, 11, 145-158. Retrieved Desember 2011

Hasro, N. (2020). Analisis Perbedaan Karyawan Kontrak Dan Karyawan Tetap Terhadap Kinerja Karyawan (Studi Kasus Pada Karyawan Bank Muamalat Kc Medan Balaikota ). Skripsi, Universitas Muhammadiyah Sumatera Utara, Program Studi Perbankan Syariah, Fakultas Agama Islam, Medan. Retrieved September 2020

Kemenperin. (2019). Analisis Perkembangan Industri Indonesia Edisi I - 2020. Kementerian Perindustrial Republik Indonesia. Jakarta: Pusdatin Kemenperin. 
Kupčák \& Šmída. (2015). Forestry And Wood Sector And Profitability Development In The Wood-Processing Industry Of The Czech Republic. Journal Of Forest Science, 61, 244-249. doi:https://doi.org/10.17221/113/2014-JFS

Kusuma, E. (2020). Analisa Perbandingan Kinerja Karyawan Tetap dan Karyawan Kontrak Pada PT Bank Mandiri (Persero) Tbk. Kcp Palembang Gedung Kanwil. Universitas Tridinanti, Manajemen, Fakultas Ekonomi. Universitas Tridinanti. Retrieved April 22, 2020

Mahaningsih, I. P., \& Kana, A. A. (2020). Analisis Perbandingan Kinerja Karyawan Tetap dan Karyawan Kontrak pada BPR Bank Daerah Gunungkidul. Cakrawangsa Bisnis, 1, 59-70. Retrieved April 2020

Mardiana, N., Desfiandi, A., \& Istari, A. (2017). HR Development And Compensation Development Strategy On The Satisfaction Of Work And Its Impact On Employee Performance. 3rd International Conferences on Information Technology and Business (ICITB), (pp. 48-61). Retrieved December 7, 2017

Mgalu, A. (2017). The Effect Of Employees' Motivation On Employees' Performance, A Case of National Social Security Fund (NSSF) Head Quarters. Dissertation, Institute of Social Work, Human Resource Management. Retrieved June 2017

Romy, M. R., Rengkung, M., \& Makarau, V. (2015). Pengaruh Perkembangan Industri Mebel Terhadap Pola Pemanfaatan Lahan Di Desa Leilem Kecamatan Sonder. Spasial : Perencanaan Wilayah Dan Kota, 1, 1-10.

Sekaran, U. (2016). Research Methods For Business Book 2 (4 ed., Vol. 1). Jakarta: Salemba Empat.

Suciu, Leonina Emilia., Lazar, Lucretia. (2013). Vroom"s Expectancy Theory. An Empirical Study Civil Servant's Performance Appraisal Influencing Expectancy. Transylvanian Review Of Administrative Sciences, 180-200.

Sugiono. (2018). Metode Penelitian Kuantitatif, Kualitatif, dan R\&D (23 ed.). Bandung: Alfabeta.

Syam, S. (2020). Pengaruh Efektifitas Dan Efisiensi Kerja Terhadap Kinerja Pegawai Pada Kantor Kecamatan Banggae Timur. Profitability: Jurnal Ilmu Manajemen, 4, 128-152. Retrieved Agustus 2020

Tabiu, A., Pangil, F., \& Othman, S. Z. (2016). Examining The Link Between Hrm Practices And Employees’ Performance In Nigerian Public Sector. Management Science Letters, 6, 395-408. doi:10.5267/j.msl.2016.4.006

Wahyuningtyas, S., \& Utami, H. N. (2018). Analisis Perbedaan Kinerja Karyawan Outsourcing Dan Karyawan Tetap (Studi Pada Karyawan Bank BRI Kantor Cabang Malang Kawi). Jurnal Administrasi Bisnis (JAB)|, 60, 96-103. Retrieved Juli 2018

Wirakusumah, A. T. (2014). Konsep Pengembangan Industri Manufaktur 2014-2019. Badan Kejuruan Teknik Industri (BKTI). Retrieved Mei 2014

Zainal, Veithzal Rivai. Basalamah, Salim., Muhammad Natsir. (2014). Islamic Human Capital Management, Managemen Sumber Daya Islami. Depok: Rajagrafindo Persada.

Conflict of Interest Statement: The authors declare that the research was conducted in the absence of any commercial or financial relationships that could be construed as a potential conflict of interest.

Copyright (C) tahun terbit nama belakang and nama belakang. This is an openaccess article distributed under the terms of the Creative Commons Attribution License (CC BY). The use, distribution or reproduction in other forums is permitted, provided the original author(s) and the copyright owner(s) are credited and that the original publi-cation in this journal is cited, in accordance with accepted academic practice. No use, distribution or reproduction is permitted which does not comply with these terms. 


\section{LIST OF TABLES}

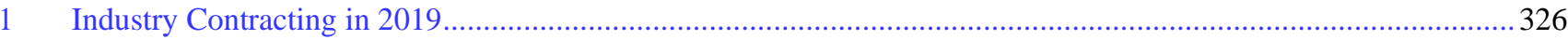

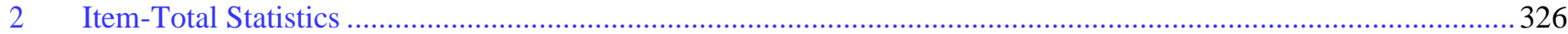

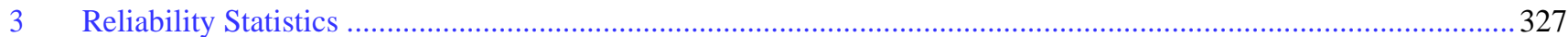

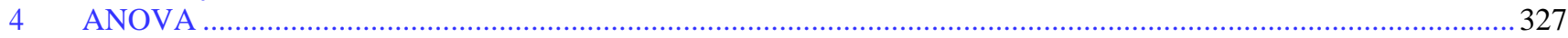

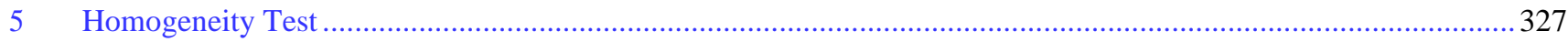

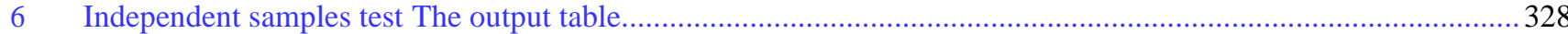

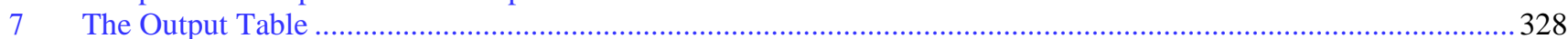


TABLE 1 | Industry Contracting in 2019

\begin{tabular}{|l|c|c|c|}
\hline \multicolumn{1}{|c|}{ Industrial Sector } & 2017 & 2018 & 2019 \\
\hline $\begin{array}{l}\text { Transport Equipment } \\
\text { Industry }\end{array}$ & 3,68 & 4,24 & - \\
\hline $\begin{array}{l}\text { Timber, Wood, Bamboo } \\
\text { and Similar Industries }\end{array}$ & 0,13 & 0,75 & - \\
\hline $\begin{array}{l}\text { Rubber Industry, Rubber } \\
\text { and Plastic Goods }\end{array}$ & 2,47 & 6,92 & 5,52 \\
\hline $\begin{array}{l}\text { Machinery \& Equipment } \\
\text { Industry }\end{array}$ & 5,55 & 9,49 & - \\
\hline
\end{tabular}

Source: Ministry of Industry, 2019 
TABLE 2 | Item-Total Statistics

\begin{tabular}{|l|r|r|r|r|}
\hline & $\begin{array}{c}\text { Scale Mean if } \\
\text { Item Deleted }\end{array}$ & $\begin{array}{r}\text { Scale Variance } \\
\text { if Item Deleted }\end{array}$ & $\begin{array}{c}\text { Corrected Item- } \\
\text { Total Correlation }\end{array}$ & $\begin{array}{c}\text { Cronbach's Alpha } \\
\text { if Item Deleted }\end{array}$ \\
\hline ITEM 1 & 19.61 & 4.341 & 0.726 & 0.729 \\
\hline ITEM 2 & 19.77 & 4.462 & 0.856 & 0.701 \\
\hline ITEM 3 & 20.06 & 3.592 & 0.698 & 0.761 \\
\hline ITEM 4 & 19.54 & 5.806 & 0.506 & 0.788 \\
\hline ITEM 5 & 19.51 & 6.414 & 0.278 & 0.821 \\
\hline ITEM 6 & 19.51 & 6.091 & 0.458 & 0.799 \\
\hline
\end{tabular}

Source: SPSS Output, 2021 
TABLE 3 | Reliability Statistics

\begin{tabular}{|c|c|}
\hline $\begin{array}{c}\text { Cronbach's } \\
\text { Alpha }\end{array}$ & $\mathrm{N}$ of Items \\
\hline .803 & 6 \\
\hline
\end{tabular}

Source : SPSS Output, 2021 
TABLE 4 | ANOVA

Employee Performance

\begin{tabular}{|l|r|r|r|c|c|}
\hline & $\begin{array}{c}\text { Sum of } \\
\text { Squares }\end{array}$ & df & $\begin{array}{c}\text { Mean } \\
\text { Square }\end{array}$ & F & Sig. \\
\hline $\begin{array}{l}\text { Between } \\
\text { Groups }\end{array}$ & 82.810 & 1 & 82.810 & 12.297 & 0.001 \\
\hline $\begin{array}{l}\text { Within } \\
\text { Groups }\end{array}$ & 659.940 & 98 & 6.734 & & \\
\hline Total & 742.750 & 99 & & & \\
\hline
\end{tabular}

Source : SPSS Output, 2021 
TABLE 5 | Homogeneity Test

\section{Group Statistics}

\begin{tabular}{|l|l|c|c|c|c|}
\hline & Group & $\mathrm{N}$ & Mean & $\begin{array}{c}\text { Std. } \\
\text { Deviatio } \\
\mathrm{n}\end{array}$ & $\begin{array}{c}\text { Std. } \\
\text { Error } \\
\text { Mean }\end{array}$ \\
\hline $\begin{array}{l}\text { Employee } \\
\text { Performanc } \\
\text { e }\end{array}$ & Permanent & 50 & 22.74 & 2.293 & 0.324 \\
\cline { 2 - 6 } & Contract & 50 & 24.56 & 2.865 & 0.405 \\
\hline
\end{tabular}

Source : SPSS Output, 2021 
TABLE 6 | Independent samples test the output table

\begin{tabular}{|lllc|}
\hline & & \multicolumn{2}{c|}{$\begin{array}{c}\text { Levene's Test for } \\
\text { Equality of Variances }\end{array}$} \\
\cline { 3 - 4 } & & F & Sig. \\
\hline Kinerja & & 0.093 & $\mathbf{0 . 7 6 1}$ \\
\cline { 3 - 4 } & $\begin{array}{l}\text { Equal variances } \\
\text { not assumed }\end{array}$ & \\
\hline
\end{tabular}

Source: SPSS Output, 2021 
TABLE 7 | The Output Table

\begin{tabular}{|c|r|r|r|r|r|r|}
\hline \multicolumn{2}{|c|}{ t-test for Equality of Means } \\
\hline & & & & & \multicolumn{2}{c|}{$\begin{array}{c}95 \% \text { Confidence } \\
\text { Interval of the } \\
\text { Difference }\end{array}$} \\
$\mathrm{t}$ & $\mathrm{df}$ & Sig. (2-tailed) & $\begin{array}{c}\text { Mean } \\
\text { Difference }\end{array}$ & $\begin{array}{c}\text { Std. Error } \\
\text { Difference }\end{array}$ & Lower & Upper \\
\hline-3.507 & 98 & 0.001 & -1.820 & 0.519 & -2.850 & -0.790 \\
\hline-3.507 & 93.505 & 0.001 & -1.820 & 0.519 & -2.851 & -0.789 \\
\hline
\end{tabular}

Source : SPSS Output, 2021 